JÓNÁS Tamás - DOMBI József -

TÓTH Zsuzsanna Eszter

\title{
AZ INTELLEKTUÁLIS TŐKE \\ MÉRÉSÉNEK ÉS ÉRTÉKELÉSÉNEK \\ KÜLÖNVÁLASZTÁSA ÉRTÉKELŐ \\ FÜGGVÉNYEK ALKALMAZÁSÁVAL
}

A tanulmány alapgondolata az intellektuális tốke mérésének és értékelésének különválasztása értékelő és abból származtatott hasznosság függvények alkalmazásával az intellektuális tốkeelemek mutatószámrendszer alapú méréseiból kiindulva. A szerzốk megközelítése lehetốvé teszi, hogy a mérốrendszer által szolgáltatott mértékeket felülértékeljék a vállalat értékrendjét megtestesító értékeló függvények segítségével. Ez utóbbi paramétereinek megfeleló kalibrálásával a vállalat intellektuális tókeelemekre vonatkozó preferenciái jutnak kifejezésre, ezért a felülértékelés eredményeként az intellektuális tốkeelemek vállalati értékének egy jobb közelítését eredményezik.*

Kulcsszavak: intellektuális tốke, tudásmenedzsment, mérési módszerek, értékelési módszerek

Az elmúlt évtizedekben számos nemzeti és nemzetközi kezdeményezés indult az intellektuális tốkeelemek azonosítására, mérésére és értékelésére (pl. Bontis, 2001; Chen et al., 2005; DATI, 1998, 1999; Edvinsson - Kivikas, 2007; Guthrie et al., 1999; Johanson et al., 2001; Kivikas - Pfeifer, 2005; KPMG, 2000; KPMGBME Akadémia-Pannon Egyetem, 2006; Lovdal Roberts, 1999). Az intellektuális tókével kapcsolatos kutatások célja a kézzelfogható eróforrások mellett a nehezen megragadható és számszerúsíthetố „puha” tényezók (így pl. a képzett és gyakorlott munkaerô, a vevókkel és más érdekelt felekkel fenntartott kapcsolatok, a szervezeti kultúra, az egyedülálló szervezeti struktúrák, eljárások) szervezeti tókeelemek közötti megjelenítése és a szervezeti sikerhez való hozzájárulásuk mérése (pl. Edvinsson - Malone, 1997; Kaplan Norton, 1996; Roos et al., 1997; Stewart, 1997; Sveiby, 1997; Waterhouse - Svendsen, 1998).

Kutatásunk az intellektuális tốke mérésének scorecard módszereire támaszkodva értékelő függvények segítségével kívánja az intellektuális tókeelemeket érintố mutatószám-alapú méréseket alkalmassá tenni a szervezet szempontjából érzékelhető hasznosságuk kifejezésére, és így a mérések megbízhatóságának növelésére. A vevő́i tốke egy kulcsfontosságú mutatószámát, a vevối elégedettséget választottuk az értékelô és az abból származtatott hasznosság függvények alkalmazásának, valamint az intellektuális tókeelemekhez kapcsolódó mérés és értékelés szétválasztásának szemléltetésére.

A hasznosság függvények aggregálásával a stratégia szempontjából kulcsfontosságúnak tekinthetô, mutatószámok segítségével mért intellektuális tốkeelemek aggregált értéke is kifejezhetô.

\section{A kutatás elméleti háttere}

Kutatásunk során az intellektuális tóke fogalma alatt a nem tárgyiasult tốkeelemek olyan kombinációját értjük, amely felett a vállalat rendelkezik, illetve amelynek eredményes és hatékony menedzselése a vállalat fenntartható versenyelónyének forrása. Az intellektuális tốke három alapvetô összetevője, nevezetesen a humán, a strukturális és a vevối tốke között a gyakorlatban nehezen húzhatók egyértelmú határok, és nem is létezhetnek egymás nélkül. 


\section{Az intellektuális tôke mérése és értékelése}

Az intellektuálistőke-összetevớk a szomszédos tókeösszetevókbe alakulhatnak át, így az intellektuális tóke menedzselése arról szól, hogy az egyes intellektuális tőkeelemek hol helyezkednek el, és milyen intézkedésekre van szükség ahhoz, hogy az elvesztés kockázatával fenyegető (humán és vevối) tốkeelemeket a vállalat strukturális tókévé alakítsa (Areopa, 2005; Andriessen, 2001; Andriessen - Tissen, 2000; Leliaert et al., 2003).

A mérési modellek felépítésének legfóbb motivációjává az vált, hogy az érdekelt felek milyen információkra kíváncsiak és azokhoz milyen formában kívánnak hozzájutni (Roos - Roos, 1997) (1. ábra).
3. a módszerek harmadik csoportja egyetlen aggregált nem pénzügyi mutatószámban kívánja megragadni az intellektuális vagyont,

4. az ún. scorecard típusú módszerek az intellektuális tốkét alkotóelemenként feltáró nem pénzügyi mutatószámokat alkalmazó módszerek.

Értékelő függvények alkalmazásán nyugvó módszerünk nem pénzügyi mutatószámok alkalmazására építve kívánja megragadni az egyes intellektuális tôkeelemek értékét. E függvényeket egyfajta hasznosság függvényként értelmezve módszerünk a scorecardokon alapuló intellektuális tókeelemek értékének az aggre-

1. ábra

A rendelkezésre álló intellektuálistóke-mérési keretrendszerek ${ }^{\mathbf{1}}$ (forrás: Sveiby, 2001-2010)

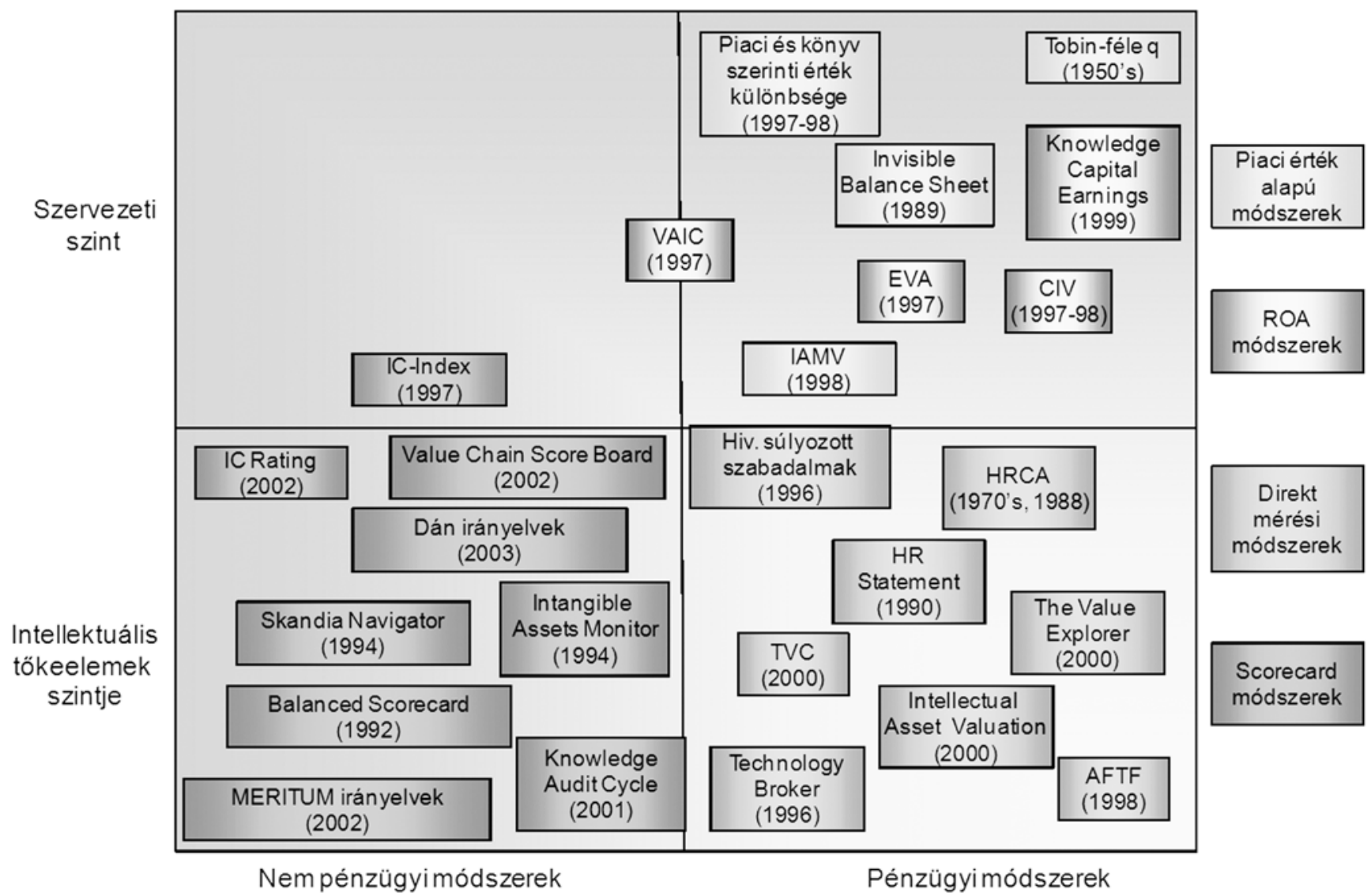

Az intellektuális tốke számbavételére irányuló mérési motivációkat alapul véve az alábbi négy kategóriát különböztethetjük meg:

1. a piaciérték-alapú és eszközmegtérülés számításán alapuló (ROA) módszerek egyetlen pénzügyi mutatószámban kívánják az intellektuális tókét megragadni,

2. a direkt módszerek az intellektuális tókét alkotóelemenként feltáró és azokhoz pénzügyi mutatószámokat rendelô módszerek, gálása felé is megnyitja az utat. Így lehetővé válik az intellektuális tốke értékének szervezeti szinten való megragadása, amelynek révén az értékelő függvények alkalmazására építő módszerünk az 1. ábra bal felsô negyedében helyezhetô el.

Andriessen (2004) a módszerek csoportosításakor a mérés és értékelés céljai és módszerei közötti lényeges különbségeket emeli ki. Az érték a hasznosság mértékeként ragadható meg. A hasznosság mértékének a megítéléséhez, vagyis az értékeléshez szükség van egy 
értékelési keretrendszerre, amely az értékelendő dologból és olyan explicit vagy implicit kritériumokból áll, amelyek az adott dolog hasznosságát, kívánatosságát fejezik ki. A 2. ábra a lehetôségeket szemlélteti.

A mérés és értékelés különválasztása (Forrás: Andriessen, 2004)

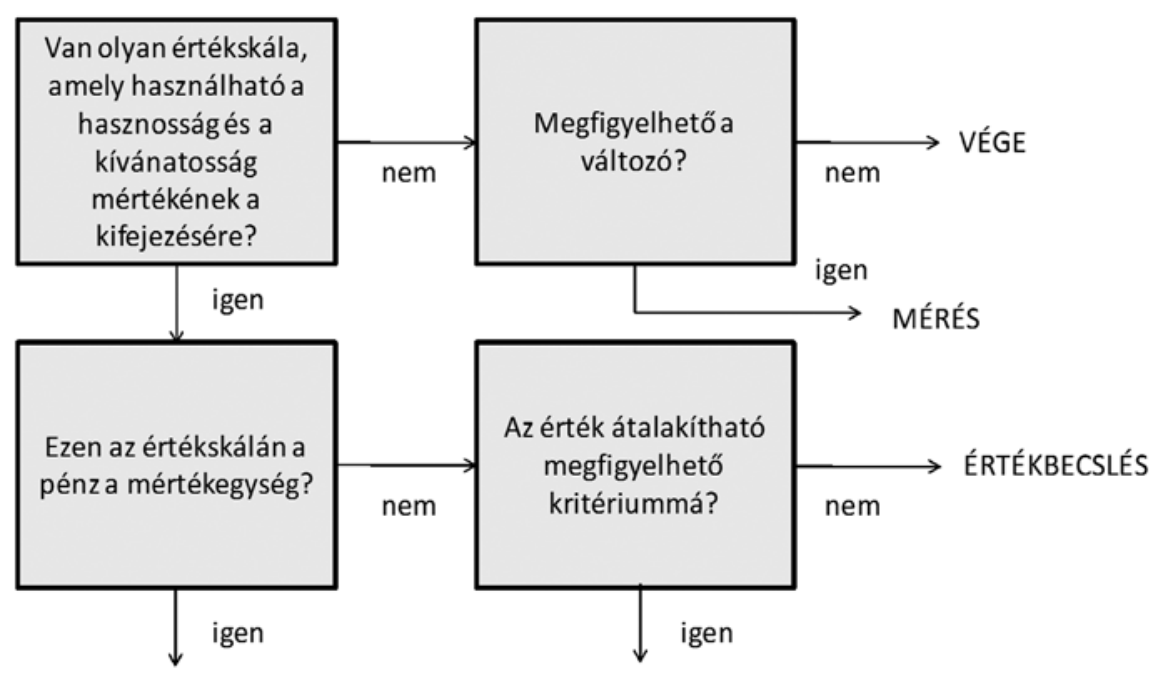

PÉNZÜGYIÉRTÉKELÉS

ÉRTÉKMÉRÉS

A különbséget meghatározó tényezók: a kritériumok értékben történő kifejezési képessége, a pénz értékméróként való használata és a mért változó vagy a kritérium megfigyelhetôsége. A mérési és értékelési módszerek közé nem tehetô egyenlőségjel.

Az intellektuális tốke mérésének egyik nehézségét az adja, hogy az érték nem mérhetố közvetlenül pénzben, és közvetve is csak igen erôs torzításokkal (Juhász, 2004). A vállalatnál pl. a szervezeti kultúra, az egyedülálló szervezeti eljárások, a márka vitathatatlan jelentôséggel bír, értéke van, de nem mérhetô pénzzel. Ugyanakkor az intellektuális tóke fejlesztése csak részenként lehetséges, nem elég a vállalat teljes IC-jét mérni, a részeket is meg kell tudni ragadni. Nemcsak az a fontos, hogy mekkora az intellektuális tớke, hanem az is, hogy az milyen elemekból tevôdik össze és milyen azok tulajdonolhatósága (Boda, 2005, 2008).

Az általunk vizsgált scorecard módszerek célja, hogy időról időre biztosítsák a szükséges információkat, hogy a menedzsment a pillanatnyi helyzetnek megfelelóen módosíthassa az IC menedzselésének stratégiáját. Következésképpen a mérési modell inkább az IC-mutatókban látható trendekre fókuszál, ahelyett, hogy minden áron gazdasági értéket számolna, így a pénzügyi mutatószámoknál az adott IC-elem természetének leírására alkalmasabb mutatószám választása a cél (Tóth, 2008).

\section{A vevôi elégedettség mérése}

A vevôi tóke a szervezeten kívüli kapcsolatokban megtestesülő tudás, fejlesztése a humán és strukturális tôkétôl érkezô támogatástól erősen függ (pl. Homburg 2. ábra - Stock, 2004; Rogelberg et al., 1999). A vevói tóke egyik kulcsfontosságú és széles körben alkalmazott mutatószáma a vevới elégedettség, amely az innováció, az ismételt vásárlások és a vevôi húség potenciális forrása (Johnsen et al., 2005; Fornell et al., 1996).

Tanulmányunk ún. Electronics Manufacturing Services (EMS) vállalatok általános, mutatószámokon alapuló vevőielégedettség-mérési gyakorlatának vizsgálatán nyugszik. A vevók időról idôre visszacsatolást adnak a szervezet felé előre rögzített mutatószámok formájában, és a vállalat teljesítményét olyan területeken számszerúsítik, mint pl. a minôség, az ellátási lánc menedzsmentje, a szállítás pontossága, a rugalmasság vagy a vevői kommunikáció. Grigoroudis et al. (2000) és Hong-Yu et al. (2006) az értékelés kritériumainak egy lehetséges keretrendszerét mutatják be, az utóbbiak kifejezetten EMS-vállalatokra szabva. Az egyes vevốk elégedettségének mértékét egy mesterségesen elóállított aggregált számérték jellemzi, amelyet a vállalat saját preferenciarendszerében értékel. Például, ha egy EMS-vállalat olyan scorecardot használ, amely a vevôi elégedettséget egy 0-tól 100-ig terjedô pontskálán méri, akkor minden egyes alkalommal, amikor a vevôt elégedettségérôl „faggatják”, a válasz valahol 0 és 100 között lesz. E válaszként adott pontértékre és a vállalat preferenciarendszerére alapozva a vevői elégedettség az 1. táblázatban látható módon értelmezhetô.

1. táblázat

Példa a vevôi elégedettség értékelésére

\begin{tabular}{|c|c|}
\hline Pontszám & A vevói elégedettség szintje \\
\hline$<20$ & Nagyon gyenge \\
\hline$>=20$ és $<40$ & Gyenge \\
\hline$>=40$ és $<60$ & Kielégíti az elvárásokat \\
\hline$>=60$ és $<80$ & Meghaladja az elvárásokat \\
\hline$>=80$ & Kitúnó \\
\hline
\end{tabular}

A továbbiakban egyetlen vevớre és pontjaira fókuszálunk a mérés és értékelés közötti különbség szemléltetése céljából. 


\section{A mérést övezö bizonytalanságok}

Az egyének, a termékkategóriák, a vevői elvárások, a szolgáltatói teljesítmény vevơi megítélése mindmind hozzájárulnak a vevői elégedettség alakulásához és annak viselkedésbeli következményeihez (Johnson - Fornell, 1991). Azt vizsgáltuk, hogy a vevő́i elégedettséget befolyásoló tényezốk hogyan ragadhatók meg a mutatószámrendszerre épülő értékelési módszerek esetén, és e módszerek a vevốk észlelt elégedettségét milyen megbízhatósággal képesek jelezni a vállalatok felé.

\section{Mérési és értékelési szerepek}

A vevői elégedettség mérésének és értékelésének szereposztása szerint a mérést pontozás útján a vevő végzi, az értékelést pedig a vállalat. A vállalat számokat kap a vevőitôl, és e számokat az értékelési kritériumokhoz hasonlítva bízik abban, hogy mindez a vevô elégedettségi szintjét tükrözi. Éppen ezért a vevốt nem arra kérik, hogy az észlelt elégedettségi szintjéról nyújtson visszacsatolást, hanem csak az az elvárás, hogy a szolgáltatóvállalat teljesítményszintjét számszerú formába öntse.

\section{Skálázás}

A vevőielégedettség-mérés eredményeként kapott 80 pont mérték valóban azt jelenti, hogy a vevő kétszer olyan elégedett, mint amikor csak 40 pontot ad? A válasz a módszer konzisztenciáját kérdójelezi meg, annak ellenére, hogy a szolgáltató vállalatok széles körben használnak ehhez hasonló módszereket. A bizonytalanság forrása az a feltételezés, hogy a vevô az elégedettségét arányskálán fejezi ki, vagyis hogy a vevő által adott pontszám arányos az általa érzékelt elégedettséggel. Amennyiben nem ez a helyzet, a vevő érzékelt elégedettségét nem lehet lineáris skálán értékelni, vagyis a vállalat vevőelégedettségi szintjére vonatkozó lineáris értékelése megkérdôjelezhetô még akkor is, ha az észszerúnek és logikusnak túnik.

\section{Szubjektivitás}

„Vevơ" alatt a szolgáltatást igénybe vevő szervezetet értjük, e szervezeteket is egyének képviselik, a tólük kapott pontokból a szubjektivitás nem iktatható ki teljesen, és így megkérdőjelezhetô a mérések ismételhetôsége és reprodukálhatósága (Burdick - Borror, 2005).

\section{Értékelő függvények}

Kutatásunk célja olyan értékelő függvények alkalmazásán alapuló módszer kidolgozása volt, amely lehetôvé teszi a vevői elégedettség mérésével és értékelésével kapcsolatban fentebb vázolt problémák kezelését. Az értékelő függvényeket olyan matematikai transzformációknak tekintjük, amelyek segítségével a scorecardalapú vevői elégedettség mérésének pontértékei a mérési skáláról egy értékelési skálára transzformálhatók.

Jelölje $m$ a vevői elégedettség mért értékét az $\left[m_{S}, m_{E}\right]$ intervallumban, ahol $m_{S}$ és $m_{E}$ a mérési skála kezdố-, illetve végpontja. Egy $E$ értékelő függvény minden $\mathrm{m} \in\left[m_{S}, m_{E}\right]$ értékhez egy $E(m)$ vevơielégedettségértéket rendel úgy, hogy a függvény rendelkezik az alábbi tulajdonságokkal:

1) A függvény monoton növekvő: magasabb mért értékekhez magasabb $E(m)$ vevôielégedettségértékeket rendel.

2) A függvény értékkészlete a $(0,1)$ vagy $[0,1]$ intervallum.

3) A függvény $m$ helyen vett $E(m)$ helyettesítési értéke a vevố azon észlelt elégedettségét fejezi ki a $(0,1)$ vagy $[0,1]$ skálán, amelyet a vevố a mért $m$ értékhez társítana.

\section{A logisztikus értékelés elméleti háttere}

EMS-cégek 23 vevőjének 30 képviselójével folytatott interjúinak eredményeként arra a következtetésre jutottunk, hogy a mutatószámalapon mért vevới elégedettségre vonatkozóan minden vevő preferenciarendszerében létezik egy küszöbszám, amelynek a vevő́k csak körülbelüli értékét tudják megadni. A vevốk szerint, ha a mért elégedettség értéke ennél a küszöbértéknél lényegesen alacsonyabb (magasabb), akkor kétségtelenül elégedetlenek (elégedettek). Ugyanakkor, ha a vevői elégedettség mért értéke e küszöbérték közelében van, akkor elégedettségükkel kapcsolatos véleményük már korántsem egyértelmú. Így a vevố elégedettségi küszöbértéke nem egy jól meghatározott, éles határvonal a mérési skálán, hanem sokkal inkább egy fuzzy-értelemben vett, gyengén definiált, elmosódott küszöbértékként értelmezhető (Hauszmann, 2006; Zadeh, 1999). Kutatási tapasztalataink alapján kijelenthető, hogy egy vevő által észlelt elégedettség csak csekély mértékben növekszik annak mért értékével, ha az észlelt elégedettség magas szintú, és fordítva, a vevő észlelt elégedettsége csak nagyon kismértékben csökken a mért értékkel, ha az észlelt elégedettség kellóen alacsony. Az észlelt vevői elégedettségnek ezt a természetét egy $E(m)$ függvény segítségével úgy ragadhatjuk meg, hogy a függvénytôl elvárjuk, hogy annak változási gyorsasága alacsony legyen akkor, ha $E(m)$ közel van az észlelt elégedettség legkisebb $E_{L}$ vagy legnagyobb $E_{H}$ értékekhez, és $E(m)$ legyen meredek, ha annak értéke mind $E_{L^{-}}$-tól, mind $E_{H^{-}}$ 
tól távol van. $\mathrm{Az} E_{L}$ és $E_{H}$ értékek az értékelési skála végpontjai a $[0,1]$ intervallumban.

A fenti tulajdonságoknak eleget tesz az alábbi, logisztikusnak nevezett függvény, amelynek számos alkalmazása ismert (pl. Verhulst, 1845; Modis, 1992; Fisher - Pry, 1971; Dombi, 1990).

$$
E_{\lambda, m_{0}, E_{m_{0}}}(m)=\frac{1}{1+\frac{1-E_{m_{0}}}{E_{m_{0}}} e^{-\lambda\left(m-m_{0}\right)}}
$$

Ha $\lambda$ pozitív, akkor a függvénygörbe $S$ alakú, ha negatív, akkor a függvény grafikonja $\mathrm{Z}$ alakot ír le.

A logisztikus függvény értékelő függvényként történô alkalmazása azonban korlátozott, mert a függvény a 0 és 1 értékeket csak határértékben veszi fel. A gyakorlatban viszont szuikség lehet arra, hogy az értékelő függvény az $\left[m_{S}, m_{E}\right]$ mérési skála végpontjaiban felvegye a 0 , illetve 1 értéket, vagy valamilyen elöre meghatározott minimális, illetve maximális észlelt elégedettségi értéket. Ezért egy olyan, a logisztikus függvényt jól közelítő függvény alkalmazását javasoljuk, amelynek helyettesítési értékei az $\left[m_{S}, m_{E}\right]$ intervallum végpontjaiban közvetlenül megadhatók.

\section{$A z E_{\omega}(m)$ értékelö függvény}

Belátható, hogy az

$$
E_{\omega, m_{S}, m_{E}, m_{0}, E_{m_{0}}, E_{L}, E_{H}}(m)=
$$

$$
=E_{L}+\left(E_{H}-E_{L}\right) \frac{\left(\frac{m-m_{S}}{m_{E}-m_{S}}\right)^{\omega}}{\left(\frac{m-m_{S}}{m_{E}-m_{S}}\right)^{\omega}+\frac{E_{H}-E_{m_{0}}}{E_{m_{0}}-E_{L}}\left[\frac{m_{0}-m_{S}}{m_{E}-m_{0}}\left(1-\frac{m-m_{S}}{m_{E}-m_{S}}\right)\right]^{\omega}}
$$

\section{Az alkalmazott módszertan} a következő lépésekból áll.

\section{$A z E_{\omega}(m)$ függvény gyakorlati alkalmazása}

$\mathrm{Az} E_{\omega}(m)$ függvénnyel egy olyan matematikai eszközhöz jutottunk, melynek segítségével a mutatószámalapon mért vevôielégedettség-értékekhez konzisztens módon hozzárendelhetók az észlelt vevôielégedettségértékek. Erre azért van szükség, mert a gyakorlati tapasztalatok azt mutatják, hogy a mutatószámok alapján mért, majd a vállalat preferenciarendszerében értékelt vevooi elégedettség általában nem képes konzisztens módon tükrözni a vevôk észlelt elégedettségét. Az $E_{\omega}(m)$ függvény a vevői elégedettség mért értékeit az értékelési skálára transzformálja, s ezzel voltaképpen egy felülértékelést hajt végre. Ezzel azonban csak akkor csökkenthető a szolgáltató vállalat preferenciarendszerében értelmezett és a vevő által észlelt elégedettség közötti eltérés, ha az értékelő függvény helyettesítési értékei az $\left[E_{L} ; E_{H}\right]$ intervallumban valóban összhangban állnak az ezen a skálán felmérhetó észlelt vevôi elégedettség értékeivel. Ennek megfelelóen kell az $E_{\omega}(m)$ függvény paramétereit megválasztani. Azt a módszert, amellyel az $E_{\omega}(m)$ függvény paramétereit úgy kalibráljuk, hogy annak alkalmazásával a mutatószámrendszer-alapú mérésból nyert mért vevőielégedettség-értékekhez a függvény által hozzárendelt elégedettségértékek és a vevő által az értékelési skálán felmérhető észlelt elégedettség közötti különbség csökkenthetô megbízhatóságalapú vevôielégedettség-értékelésnek nevezzük. A módszer

1. lépés: A vevő mutatószám-alapú mérôrendszer (általában kérdéslista) alkalmazásával fejezi ki elégedettségét.

2. lépés: A vevô a mérési skála $m_{S}$ legkisebb, illetve $m_{E}$ legnagyobb értékéhez megadja az értékelési skála

függvény az $E_{\lambda, m_{0}, E_{m_{0}}}(m)$ logisztikus függvény egy jó közelítését adja, ha $E_{L}=0, E_{H}=1$. A függvény voltaképpen egy alkalmas lineáris transzformáltja az úgynevezett $\kappa$ függvénynek, amely tagsági függvényként alkalmazható a fuzzy-elméletben (Dombi, 1990).

Az $\omega$ paraméter megválasztásának és a közelítéssel kapcsolatos részleteknek a bemutatásától e cikk keretein belül eltekintünk (lásd Jónás, 2010 cikkét). Az egyszerúbb írásmód kedvéért a továbbiakban az $E_{\omega}(m)$ rövidített jelölést használjuk az $E_{\omega, m_{S}, m_{E}, m_{0}, E_{m n}, E_{L}, E_{H}}\left(\begin{array}{c}\omega \\ m\end{array}\right)$ helyett.
$E_{L}$ alsó, illetve $E_{H}$ felsô végpontjait. Ezzel az $E_{\omega}(m)$ függvény ablakparaméterei adottak. A vevő beállítja, hogy mennyire lenne elégedett a [0;1] skálán, ha a mérési pontszám minimális, illetve maximális lenne.

3. lépés: $\mathrm{Az} E_{\omega}(m)$ függvény $m_{0}, E_{m_{0}}$ és $\omega$ paramétereit kell még meghatároznunk ahhoz, hogy a függvény egyértelmúen adott legyen. A függvénygörbe $\left(m_{0}, E_{m_{0}}\right)$ pontja közvetlenül kijelölhető $\left(m_{S}<m_{0}<m_{E}\right),\left(E_{L}<E_{m_{0}}<\right.$ $\left.E_{H}\right)$. Az $m_{0}$-nak a mérési skála középpontját ajánljuk, így azt kérdezzük meg a vevôtôl, hogy mennyi lenne elégedettségének mértéke az $\left[E_{L}, E_{H}\right]$ skálán, ha az elégedettség mért értéke a mérési skála középértéke lenne. 
4. lépés: $\mathrm{Az} \omega$ meghatározásához azt kérjük a vevőtól, hogy adja meg a függvénygörbe egy további tetszóleges $\left(m_{a}, E_{m_{a}}\right)$ pontját. Mivel $\left(m_{a}, E_{m_{a}}\right)$ az $E_{\omega}(m)$ függvénygörbe egy pontja, ezért teljesül az

$$
E_{m_{a}}=E_{L}+\left(E_{H}-E_{L}\right) \frac{\left(\frac{m_{a}-m_{S}}{m_{E}-m_{S}}\right)^{\omega}}{\left(\frac{m_{a}-m_{S}}{m_{E}-m_{S}}\right)^{\omega}+\frac{E_{H}-E_{m_{0}}}{E_{m_{0}}-E_{L}}\left[\frac{m_{0}-m_{S}}{m_{E}-m_{0}}\left(1-\frac{m_{a}-m_{S}}{m_{E}-m_{S}}\right)\right]^{\omega}},
$$

A fenti számítás, illetve az $E_{\omega}(m)$ függvény alkalmazása akkor helyes, ha elfogadjuk, hogy a vevő észlelt elégedettsége és a mért elégedettség közötti függóségi viszony logisztikus vagy közel logisztikus függvénnyel leírható.

\section{Aggregált értékelés}

Amegbízhatóságalapú vevőielégedettség-értékelési módszer alapja egy mutatószám-alapú egyenlőség, ebből pedig

$$
\omega=\frac{\ln \left(\frac{E_{H}-E_{m_{a}}}{E_{m_{a}}-E_{L}} \frac{E_{m_{0}}-E_{L}}{E_{H}-E_{m_{0}}}\right)}{\ln \left(\frac{m_{E}-m_{a}}{m_{a}-m_{S}} \frac{m_{0}-m_{S}}{m_{E}-m_{0}}\right)}
$$

mérési módszer, amely már önmagában is aggregált, hiszen kimenete általában egy kérdéslista alapján nyert pontértékek aggregátumaként áll elő.

A vállalati gyakorlatban egy szolgáltató vállalatnak általában több vevôje van, és igényeik nagyon különbözőek lehetnek. EMS-cégeket vizsgálva azt tapasztaltuk, hogy több vevô esetén vevốkre szabható értékelő kérdéslistát alkalmaznak, vagyis a kérdésekhez olyan súlyszámokat rendelnek, amelyekkel az egyes vevók számára fontos teljesítménytényezók fontossága állítható. A szolgáltató vállalat számára természetesen fontos, hogy minden vevő elégedettségét megértse, de az is lényeges, hogy a vállalat tevékenysége összességében mennyire képes kielégíteni a vevơi által támasztott igényeket. A kérdés tehát az, hogy a vevớk észlelt elégedettsége hogyan összesíthetô.

$\mathrm{Az} E_{\omega}(m)$ értékelő függvény vevônkénti alkalmazásának egyik elónye abban áll, hogy a függvény értékkészlete minden vevố esetén a $[0,1]$ intervallum valamely részhalmaza, függetlenül attól, hogy a vevői elégedettség mérésére alkalmazott kérdéslistákban az egyes kérdések milyen súllyal szerepelnek. Ez a közös értékelési tartomány lehetôvé teszi, hogy az azonos mérési skálán értelmezett értékelô függvényeket aggregáljuk. Fontos látnunk, hogy csak a mérési skáláknak kell azonosnak lenniük, a hozzájuk tartozó kérdéslistáknak nem.

A vevői elégedettség aggregálásának alapfeltételezése az, hogy ha minden vevő észlelt elégedettsége egy-egy $E_{\omega}(m)$ függvénnyel írható le a mért elégedettség függvényeként, akkor a vevők aggregált észlelt elégedettsége szintén egy - a közös mérési skálán értelmezett $-E_{\omega}(m)$ típusú függvénnyel modellezhetô.

Tegyük fel, hogy egy szolgáltató vállalatnak $n$ vevője van, és a vállalat minden egyes vevóje esetén olyan mutatószám-alapú elégedettség mérési módszert alkalmaz, melynek kimenete egy közös mérési skálán helyezhetô el. Ha minden vevőre alkalmazzuk a módszerünket, akkor $n$ darab $E_{\omega}^{(i)}(m)$ értékelő függvényhez jutunk. Jelölje $\omega^{(i)}, m_{S}^{(i)}, m_{E}^{(i)}, m_{0}^{(i)}, E_{m_{0}}^{(i)}, E_{L}^{(i)}$ és $E_{H}^{(i)}$ az $i$-edik 
értékelő függvény paramétereit $(i=1,2, \ldots, n)$. A vállalat egyes vevői is különböző jelentôséggel bírhatnak, ezért jelölje $w$ az $i$-edik vevőhöz rendelt súlyt, miközben

$$
\sum_{i=1}^{n} w_{i}=1
$$

Mivel azt feltételeztük, hogy a mérési skála minden egyes vevô esetén azonos, és megegyezik az aggregált értékelő függvény $\left[m_{S}^{(A)}, m_{E}^{(A)}\right]$ mérési skálájával, ezért $m_{S}^{(i)}=m_{S}^{(A)}$ és $m_{E}^{(i)}=m_{E}^{(A)}$ minden $(i=1,2, \ldots, n)$ esetén. Az aggregált $E_{\omega}^{(A)}(m)$ értékelő függvény $\omega^{(A)}, m_{0}^{(A)}, E_{m_{0}}^{(A)}$, $E_{L}^{(A)}$ és $E_{H}^{(A)}$ paraméterei pedig az egyes $E_{\omega}^{(i)}(m)$ függvények megfelelő paramétereinek $w_{i}$ súlyokkal vett súlyozott átlagértékeiként határozhatók meg, azaz:

$$
\begin{aligned}
& \underline{\omega^{(A)}=\sum_{i=1}^{n} w_{i} \omega^{(i)},}, \underline{m_{0}^{(A)}=\sum_{i=1}^{n} w_{i} m_{0}^{(i)}, E_{m_{0}}^{(A)}=\sum_{i=1}^{n} w_{i} E_{m_{0}}^{(i)},} \\
& E_{L}^{(A)}=\sum_{i=1}^{n} w_{i} E_{L}^{(i)}, E_{H}^{(A)}=\sum_{i=1}^{n} w_{i} E_{H}^{(i)}
\end{aligned}
$$

$(i=1,2, \ldots, n)$.

Ezt paraméter-súlyozású aggregált vevôielégedettség-értékelö módszernek nevezzük.

\section{Hasznossági nézópont}

A bemutatott vevôielégedettség-értékelési módszer egy lehetséges módja annak, hogy egy szolgáltató vállalat konzisztens módon jusson vevói visszajelzésekhez a teljesítményére vonatkozóan. Ebben az értelemben az észlelt vevói elégedettség a vállalat teljesítményének egy mérése a vevố preferenciarendszerében. Ugyanezt a vevő oldaláról szemlélve úgy is tekinthetjük, hogy a vevő észlelt elégedettsége annak a hasznosságnak a kifejeződése, amelyet a vevő a szolgáltató vállalat által nyújtott teljesítmény kapcsán észlel. Eszerint az észlelt vevői elégedettséget a mutatószám-alapú mért elégedettség függvényeként kifejező értékelő függvényeket hasznosság függvényeknek is tekinthetjük, mégpedig olyan speciális hasznosság függvényeknek, amelyek a mutatószámalapon mért vállalati teljesítményhez annak vevő által észlelt hasznosságát rendelik.

A vevơi elégedettséget a vállalat egy intellektuális tóke indikátorának tekintve elmondhatjuk, hogy egy több vevő visszajelzései alapján megkonstruált aggregált vevőielégedettség-értékelő függvény nem más, mint a tôkeelemhez kapcsolt hasznosság függvény, amely a tókeelem mutatószám-alapú mért értékeihez, azok vevớk által észlelt aggregált hasznosságát rendeli.
E gondolatmenetet követve elmondhatjuk, hogy tetszôleges intellektuális tókeelemhez egy, a fenti értelemben vett hasznosság függvény társítható, ha a tôkeelemre vonatkozóan rendelkezünk egy mutatószám-alapú mérési módszerrel.

\section{Intellektuális tókeelemek hasznosságának aggregálása}

A fentiek alapján a megbízhatóságalapú vevőielégedettség-értékelőmódszerbármely, mutatószámalapon mért intellektuális tốkeelem értékelésére alkalmazható. Ezt az általánosított módszert megbízhatóságalapú intellektuális tốkelem-értékelési módszernek nevezzük. A módszert egy intellektuális tókeelemre (ITE) alkalmazva olyan hasznosság függvényhez jutunk, amely a tókeelem mutatószám-alapú mért értékeihez a vállalat számára nyújtott hasznosságukat rendeli. Ha ugyanazon intellektuális tốkeelemre vonatkozóan több, különböző értékelő forrásokból származó hasznosság függvény is rendelkezésre áll, akkor ezek a paramétersúlyozású aggregált vevơielégedettség-értékelő módszer szerint aggregálhatók egy hasznosság függvénnyé. Ezt az általánosított aggregálási módszert paramétersúlyozású aggregált intellektuális tốkeelem-értékelési módszernek nevezzük.

A 3. ábrán összefoglaltuk, hogy az eddig bemutatott módszerek miként alkalmazhatók a pillanatnyilag mért intellektuális tőkeelemek hasznosságának meghatározására. Tegyük fel, hogy $n$ darab intellektuális tôkkeelem (ITE 1,..., ITE $n$ ) aktuális hasznosságát szeretnénk meghatározni. Minden egyes ITE esetén rendelkezésünkre áll egy mutatószám-alapú mérőrendszer, amely minden egyes ITE mért értékét egy mutatószámban összegzi (mutatószám 1, ..., mutatószám $n$ ). A megbízhatóságalapú intellektuális tốkelem-értékelési módszert alkalmazva minden ITE-re, minden értékelő személy előállítja a hasznosság (értékelő) függvényét. Ha ugyanarra az ITE-re több értékelő forrásból több hasznosság (értékelő) függvény is rendelkezésre áll, akkor azokat a paraméter-súlyozású aggregált intellektuális tókeelem-értékelési módszerrel egy hasznosság (értékelő) függvénnyé aggregáljuk. Minden tókeelemre aggregáljuk a mutatószám aktuális értékét, majd ezt a megfelelő aggregált hasznosság (értékelô) függvénybe helyettesítve megkapjuk az adott ITE aktuális hasznosságát (ITE 1 aktuális hasznossága, ..., ITE $n$ aktuális hasznossága). Fontos látnunk, hogy ezek nem függvények, hanem tényleges származtatott hasznosság-értékek a $[0,1]$ intervallumban. Az így kapott hasznosságértékeket az egyes ITE-hez rendelt súlyszámok figyelembevételével egy aktuális hasznosságértékké aggregálhatjuk. 


\section{Intellektuális tớkeelemek hasznosságának aggregálási sémája}

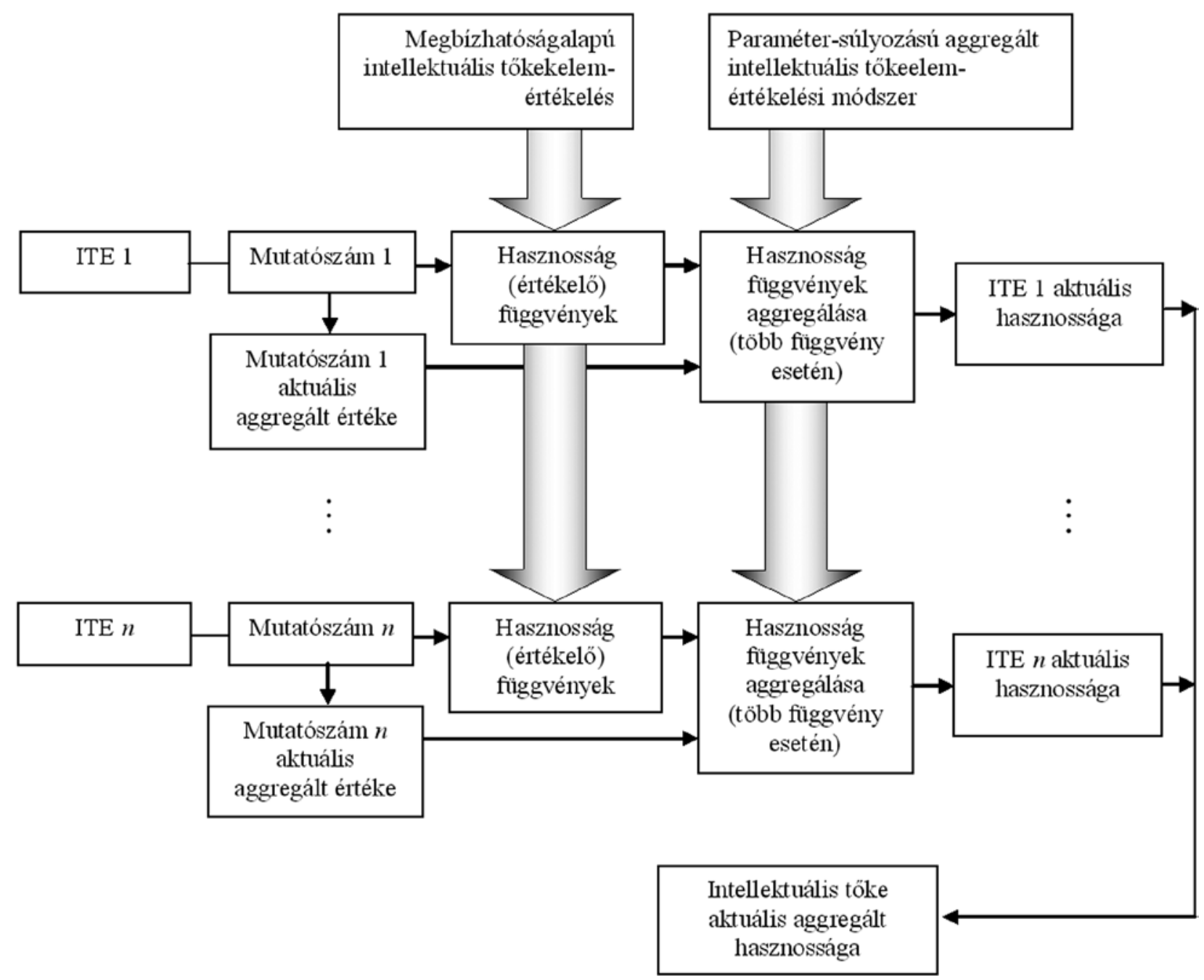

A bemutatott módszerek előnye abban áll, hogy a hasznosság függvények és az aggregált hasznosság függvények helyettesítési értékei, valamint az aktuális származtatott hasznosságok értékei mind a $[0,1]$ intervallumban elhelyezkedő számértékek. Ez lehetôvé teszi e hasznosságok aggregálását függetlenül attól, hogy ezeket a tókeelemeket milyen mutatószám-alapú módszerrel mérjük.

\section{Esettanulmány}

Egy elektronikai gyártási szolgáltatásokat nyújtó vállalat a 2. táblázat szerinti mérőrendszert (mutatórendszert) alkalmazza vevői elégedettségének mérésére. A vállalatnak összesen 23 másik vállalkozás a vevôje, akiknek lehetôségük van arra, hogy az egyes mérési kategóriákhoz súlyszámokat rendelve kifejezzék azok fontosságát. E súlyszámokat a 2. táblázat tartalmazza.
Minden vevố minden mérési kategóriában a 0-tól 100 pontig terjedô skálán pontozhatja a szolgáltató vállalat teljesítményét. A vevốk által adott pontokat, valamint a vevốk mérési kategóriákhoz rendelt súlyszámai alapján számított aggregált (súlyozottan átlagolt) pontszámokat a 3. táblázat tartalmazza.

A következő két táblázat által összefoglalt módszer egyhagyományosmutatószám-alapú vevơielégedettségmérés sémáját mutatja. A vállalat - a fentieken túl - további három kérdést tett fel vevőinek annak érdekében, hogy értékelő függvények segítségével értékelje, majd aggregálja a vevôk érzékelt elégedettségét. A kérdések a következók:

1) Mekkora értékú elégedettséget érzékelne a $(0,1)$ skálán (két tizedes jegyig), ha a mérőrendszer alapján 50 pontot adna vállalatunk teljesítményére? 


\begin{tabular}{|c|c|c|c|c|c|c|c|c|c|c|c|c|c|c|c|c|c|}
\hline \multicolumn{18}{|c|}{ Mérési kategóriák és a hozzájuk rendelt súlyszámok } \\
\hline $\begin{array}{l}\text { "0े } \\
\text { : }\end{array}$ & 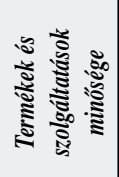 & 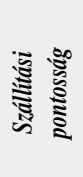 & 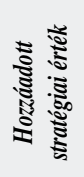 & 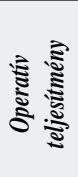 & 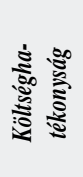 & 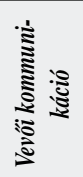 & 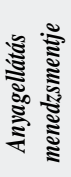 & 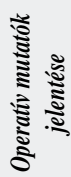 & 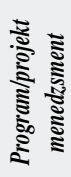 & 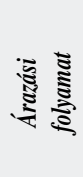 & 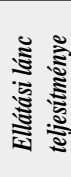 & 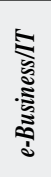 & 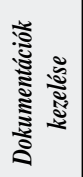 & 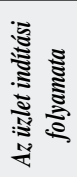 & 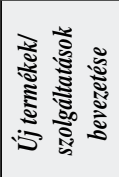 & 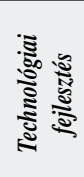 & 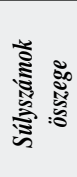 \\
\hline 1 & 12 & 12 & 12 & 11 & 10 & 6 & 8 & 5 & 4 & 3 & 3 & 4 & 3 & 3 & 2 & 2 & 100 \\
\hline 2 & 20 & 20 & 4 & 10 & 5 & 6 & 5 & 5 & 4 & 3 & 3 & 4 & 3 & 5 & 2 & 1 & 100 \\
\hline 3 & 10 & 25 & 10 & 10 & 15 & 5 & 5 & 3 & 4 & & 3 & 4 & 2 & 3 & 1 & & 100 \\
\hline 4 & 10 & 5 & 5 & 10 & 25 & 6 & 5 & 5 & 10 & 1 & 3 & 2 & 2 & 10 & & 1 & 100 \\
\hline 5 & 30 & 15 & 15 & 15 & 15 & 5 & 1 & 1 & 1 & 1 & 1 & & & & & & 100 \\
\hline 6 & 5 & 20 & 10 & 10 & 5 & 3 & 25 & 5 & 3 & & 4 & 4 & 3 & 3 & & & 100 \\
\hline 7 & 5 & 5 & 5 & 5 & 5 & 5 & 25 & 5 & 4 & & 25 & 4 & 4 & 3 & & & 100 \\
\hline 8 & 10 & 15 & 10 & 10 & 5 & 10 & 5 & 5 & 5 & 5 & 5 & & 5 & 5 & 5 & & 100 \\
\hline 9 & 12 & 15 & 13 & 15 & 10 & 3 & & 2 & 5 & & & 15 & 5 & 5 & & & 100 \\
\hline 10 & 5 & 5 & 5 & 5 & 30 & 10 & 5 & 5 & 5 & & 5 & 5 & 5 & 5 & & 5 & 100 \\
\hline 11 & 45 & 10 & 5 & 10 & 5 & 5 & & & 5 & & & 10 & & 5 & & & 100 \\
\hline 12 & 30 & 10 & 20 & 10 & 10 & 5 & & & & & 10 & & & & & 5 & 100 \\
\hline 13 & 10 & 45 & & 10 & 10 & & 5 & 5 & 10 & & 5 & & & & & & 100 \\
\hline 14 & 22 & 13 & 5 & 10 & 10 & 3 & 6 & 7 & 10 & & 3 & & 3 & 5 & & 3 & 100 \\
\hline 15 & 10 & 5 & 5 & 5 & 20 & 5 & 5 & 5 & 5 & 5 & 5 & 5 & 5 & 5 & 5 & 5 & 100 \\
\hline 16 & 5 & 10 & 5 & 10 & 40 & 5 & & 10 & & & & & & & & 15 & 100 \\
\hline 17 & 5 & 35 & 5 & 10 & 10 & 5 & 5 & 5 & 5 & & 5 & & 5 & & & 5 & 100 \\
\hline 18 & 25 & 15 & 15 & 10 & 5 & 5 & & & 5 & & & 15 & & 5 & & & 100 \\
\hline 19 & 10 & 12 & 12 & 8 & 8 & 8 & 8 & 4 & 4 & 4 & 5 & 3 & 5 & 5 & 2 & 2 & 100 \\
\hline 20 & 15 & 15 & 15 & 10 & 5 & 5 & 5 & & & & & 10 & 10 & 10 & & & 100 \\
\hline 21 & 50 & 3 & 3 & 3 & 8 & 3 & 3 & 3 & 3 & 3 & 3 & 3 & 3 & 3 & 3 & 3 & 100 \\
\hline 22 & 10 & 45 & 7 & 7 & 5 & 6 & 6 & 2 & 3 & 2 & 3 & 3 & 1 & & & & 100 \\
\hline 23 & 35 & & 20 & 20 & 10 & & & 5 & & & & 10 & & & & & 100 \\
\hline
\end{tabular}

Vevôi mérések eredménye

3. táblázat

\begin{tabular}{|c|c|c|c|c|c|c|c|c|c|c|c|c|c|c|c|c|c|}
\hline \multicolumn{18}{|c|}{ Mérési kategória - vevối pontszámok } \\
\hline 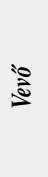 & 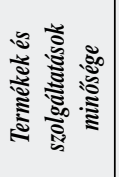 & 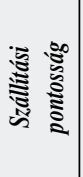 & 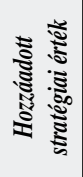 & 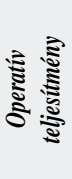 & 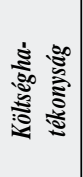 & 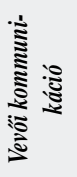 & 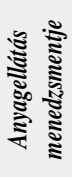 & 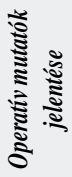 & 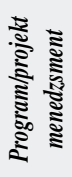 & 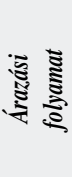 & 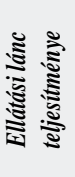 & 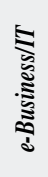 & 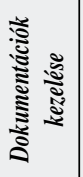 & 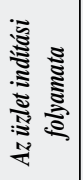 & 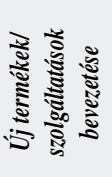 & 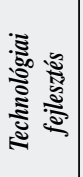 & 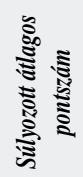 \\
\hline 1 & 68 & 70 & 92 & 72 & 50 & 90 & 85 & 92 & 90 & 95 & 80 & 92 & 95 & 88 & 95 & 82 & $\mathbf{7 8 , 8 8}$ \\
\hline 2 & 82 & 95 & 93 & 92 & 70 & 76 & 92 & 82 & 84 & 85 & 85 & 87 & 68 & 92 & 63 & 82 & 85,74 \\
\hline 3 & 95 & 90 & 92 & 90 & 88 & 80 & 91 & 85 & 85 & & 95 & 95 & 90 & 90 & 85 & & 89,90 \\
\hline 4 & 85 & 95 & 90 & 95 & 85 & 92 & 95 & 92 & 90 & 90 & 95 & 85 & 80 & 90 & & 95 & 89,37 \\
\hline 5 & 80 & 85 & 75 & 75 & 60 & 80 & 82 & 80 & 85 & 75 & 80 & & & & & & $\mathbf{7 6 , 2 7}$ \\
\hline 6 & 92 & 95 & 88 & 95 & 80 & 95 & 95 & 93 & 93 & & 91 & 95 & 92 & 88 & & & 92,78 \\
\hline 7 & 85 & 80 & 88 & 83 & 75 & 85 & 82 & 83 & 85 & & 75 & 77 & 68 & 92 & & & 80,16 \\
\hline 8 & 76 & 92 & 88 & 72 & 92 & 77 & 75 & 75 & 73 & 82 & 73 & & 88 & 85 & 87 & & 81,60 \\
\hline 9 & 92 & 91 & 90 & 88 & 94 & 91 & & 97 & 91 & & & 91 & 91 & 93 & & & 91,06 \\
\hline 10 & 83 & 82 & 74 & 82 & 81 & 82 & 88 & 91 & 82 & & 80 & 81 & 87 & 89 & & 91 & 83,00 \\
\hline 11 & 77 & 69 & 65 & 72 & 69 & 71 & & & 72 & & & 75 & & 69 & & & 73,55 \\
\hline 12 & 82 & 67 & 91 & 90 & 92 & 85 & & & & & 84 & & & & & 85 & 84,60 \\
\hline 13 & 91 & 90 & & 88 & 97 & & 92 & 93 & 91 & & 89 & & & & & & 90,90 \\
\hline 14 & 78 & 77 & 62 & 51 & 82 & 90 & 91 & 87 & 86 & & 92 & & 91 & 90 & & 88 & 79,05 \\
\hline 15 & 88 & 92 & 94 & 94 & 81 & 91 & 88 & 89 & 87 & 82 & 82 & 92 & 91 & 92 & 93 & 95 & 88,10 \\
\hline 16 & 95 & 78 & 92 & 97 & 83 & 99 & & 76 & & & & & & & & 76 & 84,00 \\
\hline 17 & 92 & 77 & 91 & 72 & 73 & 75 & 69 & 71 & 74 & & 68 & & 73 & & & 75 & 75,85 \\
\hline 18 & 78 & 87 & 88 & 91 & 97 & 92 & & & 89 & & & 89 & & 91 & & & 86,65 \\
\hline 19 & 94 & 63 & 78 & 79 & 79 & 65 & 64 & 62 & 78 & 88 & 83 & 76 & 76 & 72 & 77 & 72 & 75,21 \\
\hline 20 & 65 & 62 & 68 & 61 & 72 & 71 & 78 & & & & & 63 & 62 & 67 & & & 65,60 \\
\hline 21 & 89 & 97 & 95 & 98 & 92 & 93 & 95 & 91 & 89 & 94 & 93 & 92 & 91 & 92 & 92 & 93 & 91,01 \\
\hline 22 & 72 & 68 & 69 & 69 & 71 & 70 & 70 & 82 & 75 & 75 & 72 & 81 & 78 & & & & 70,17 \\
\hline 23 & 93 & & 85 & 83 & 82 & & & 91 & & & & 87 & & & & & 87,60 \\
\hline
\end{tabular}


2) Mekkora értékú elégedettséget érzékelne a $(0,1)$ skálán (két tizedesjegyig), ha a mérőrendszer alapján 90 pontot adna vállalatunk teljesítményére?

3) Jelenleg mekkora értékú elégedettséget érzékel szolgáltatásainkkal kapcsolatban a $(0 ; 1)$ skálán (két tizedesjegyig)?

Az első és második kérdés segítségével kalibrálhatók az egyes vevốkhöz tartozó értékelő függvények. A harmadik kérdés ellenőrzó kérdés, az arra adott válasz révén mérhető az értékelő függvények ,jósága”. Ezáltal egy értékelő függvény mért pontszámnál számított helyettesítési értéke és a vevố által érzékelt elégedettség összehasonlíthatóvá válik.

A korábbi jelöléseket alkalmazva a vállalat mind a 23 vevő́ esetén az $m_{S}=0, m_{E}=100, m_{0}=50, m_{a}=90$, $E_{L}=0, E_{H}=1$ paramétereket alkalmazta, továbbá minden vevôtól megkérdezte az $E_{m_{0}}$ és $E_{m_{a}}$ értékeket. A vállalat súlyszámokat rendelt a vevóihez aszerint, hogy azok mekkora mértékben járulnak hozzá a vállalat teljes árbevételéhez.
A 4. táblázat összegzi a vevơi inputok alapján kalibrált értékelő függvények paramétereit, a vevókhöz rendelt súlyszámok alapján az aggregált értékelő függvény paramétereit, az egyes értékelő függvények helyettesítési értékeit az aggregált vevối pontszámnál, valamint az egyes vevők által adott pontszámhoz társított érzékelt elégedettséget.

A 4. ábra az egyes hasznosság (értékelô) függvények és az aggregált hasznosság (értékelő) függvény grafikonjait mutatja.

\section{Az eredmények értékelése}

Annak érdekében, hogy képet kapjunk a megbízhatóságalapú vevooielégedettség-értékelési módszer jóságáról, statisztikai eszközökkel hasonlítottuk öszsze az észlelt vevôi elégedettség eltérését az értékeló függvény helyettesítési értékétôl (ÉVE-ÉHÉVP), valamint az észlelt vevôii elégedettség eltérését a lineárisan transzformált vevối pontszámtól (ÉVE-LTVP) minden vevőre. Ezeket a különbségeket mutatja az 5. táblázat.

Értékelố függvények paraméterei, helyettesítési értékei és

4. táblázat a vevốk által érzékelt elégedettség ${ }^{2}$

\begin{tabular}{|c|c|c|c|c|c|c|c|c|c|c|c|c|c|c|}
\hline Vevố & $\boldsymbol{A P}$ & $E_{L}^{(i)}$ & $E_{H}^{(i)}$ & $m_{s}^{(i)}$ & $m_{E}^{(i)}$ & $m_{0}^{(i)}$ & $E_{m_{0}}^{(i)}$ & $m_{a}^{(i)}$ & $E_{m_{a}}^{(i)}$ & $\omega_{i}$ & $\begin{array}{c}V S \\
(\%)\end{array}$ & 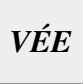 & ÉHÉVP & LTVP \\
\hline 1 & 78,88 & 0 & 1 & 0 & 100 & 50 & 0,05 & 90,00 & 0,90 & 2,34 & $10 \%$ & 0,50 & 0,5347 & 0,7888 \\
\hline 2 & 85,74 & 0 & 1 & 0 & 100 & 50 & 0,10 & 90,00 & 0,85 & 1,79 & $5 \%$ & 0,75 & 0,7336 & 0,8574 \\
\hline 3 & 89,90 & 0 & 1 & 0 & 100 & 50 & 0,05 & 90,00 & 0,95 & 2,68 & $2 \%$ & 0,95 & 0,9486 & 0,8990 \\
\hline 4 & 89,37 & 0 & 1 & 0 & 100 & 50 & 0,20 & 90,00 & 0,80 & 1,26 & $20 \%$ & 0,80 & 0,7859 & 0,8937 \\
\hline 5 & 76,27 & 0 & 1 & 0 & 100 & 50 & 0,10 & 90,00 & 0,98 & 2,77 & $3 \%$ & 0,75 & 0,7385 & 0,7627 \\
\hline 6 & 92,78 & 0 & 1 & 0 & 100 & 50 & 0,15 & 90,00 & 0,90 & 1,79 & $3 \%$ & 1,00 & 0,9445 & 0,9278 \\
\hline 7 & 80,16 & 0 & 1 & 0 & 100 & 50 & 0,10 & 90,00 & 0,85 & 1,79 & $4 \%$ & 0,60 & 0,5748 & 0,8016 \\
\hline 8 & 81,60 & 0 & 1 & 0 & 100 & 50 & 0,20 & 90,00 & 0,80 & 1,26 & $5 \%$ & 0,65 & 0,6209 & 0,8160 \\
\hline 9 & 91,06 & 0 & 1 & 0 & 100 & 50 & 0,10 & 90,00 & 0,95 & 2,34 & $6 \%$ & 0,95 & 0,9621 & 0,9106 \\
\hline 10 & 83,00 & 0 & 1 & 0 & 100 & 50 & 0,10 & 90,00 & 0,95 & 2,34 & $4 \%$ & 0,80 & 0,8195 & 0,8300 \\
\hline 11 & 73,55 & 0 & 1 & 0 & 100 & 50 & 0,40 & 90,00 & 0,90 & 1,18 & $4 \%$ & 0,70 & 0,6913 & 0,7355 \\
\hline 12 & 84,60 & 0 & 1 & 0 & 100 & 50 & 0,30 & 90,00 & 0,85 & 1,18 & $2 \%$ & 0,75 & 0,7603 & 0,8460 \\
\hline 13 & 90,90 & 0 & 1 & 0 & 100 & 50 & 0,35 & 90,00 & 0,95 & 1,62 & $2 \%$ & 0,95 & 0,9574 & 0,9090 \\
\hline 14 & 79,05 & 0 & 1 & 0 & 100 & 50 & 0,25 & 90,00 & 0,90 & 1,50 & $3 \%$ & 0,70 & 0,7096 & 0,7905 \\
\hline 15 & 88,10 & 0 & 1 & 0 & 100 & 50 & 0,40 & 90,00 & 0,87 & 1,05 & $2 \%$ & 0,85 & 0,8450 & 0,8810 \\
\hline 16 & 84,00 & 0 & 1 & 0 & 100 & 50 & 0,30 & 90,00 & 0,95 & 1,73 & $6 \%$ & 0,90 & 0,8823 & 0,8400 \\
\hline 17 & 75,85 & 0 & 1 & 0 & 100 & 50 & 0,20 & 90,00 & 0,95 & 1,97 & $2 \%$ & 0,70 & 0,7046 & 0,7585 \\
\hline 18 & 86,65 & 0 & 1 & 0 & 100 & 50 & 0,40 & 90,00 & 0,95 & 1,52 & $2 \%$ & 0,95 & 0,9203 & 0,8665 \\
\hline 19 & 75,21 & 0 & 1 & 0 & 100 & 50 & 0,35 & 90,00 & 0,85 & 1,07 & $5 \%$ & 0,70 & 0,6387 & 0,7521 \\
\hline 20 & 65,60 & 0 & 1 & 0 & 100 & 50 & 0,30 & 90,00 & 0,95 & 1,73 & $2 \%$ & 0,50 & 0,5663 & 0,6560 \\
\hline 21 & 91,01 & 0 & 1 & 0 & 100 & 50 & 0,20 & 90,00 & 0,95 & 1,97 & $2 \%$ & 0,95 & 0,9599 & 0,9101 \\
\hline 22 & 70,17 & 0 & 1 & 0 & 100 & 50 & 0,10 & 90,00 & 0,85 & 1,79 & $2 \%$ & 0,30 & 0,3393 & 0,7017 \\
\hline 23 & 87,60 & 0 & 1 & 0 & 100 & 50 & 0,25 & 90,00 & 0,90 & 1,50 & $4 \%$ & 0,85 & 0,8622 & 0,8760 \\
\hline Aggr. & 83,66 & 0 & 1 & 0 & 100 & 50 & 0,20 & 90,00 & 0,88 & 1,70 & $100 \%$ & 0,76 & 0,7507 & 0,8366 \\
\hline
\end{tabular}




\section{Hasznosság (értékelô) függvények}

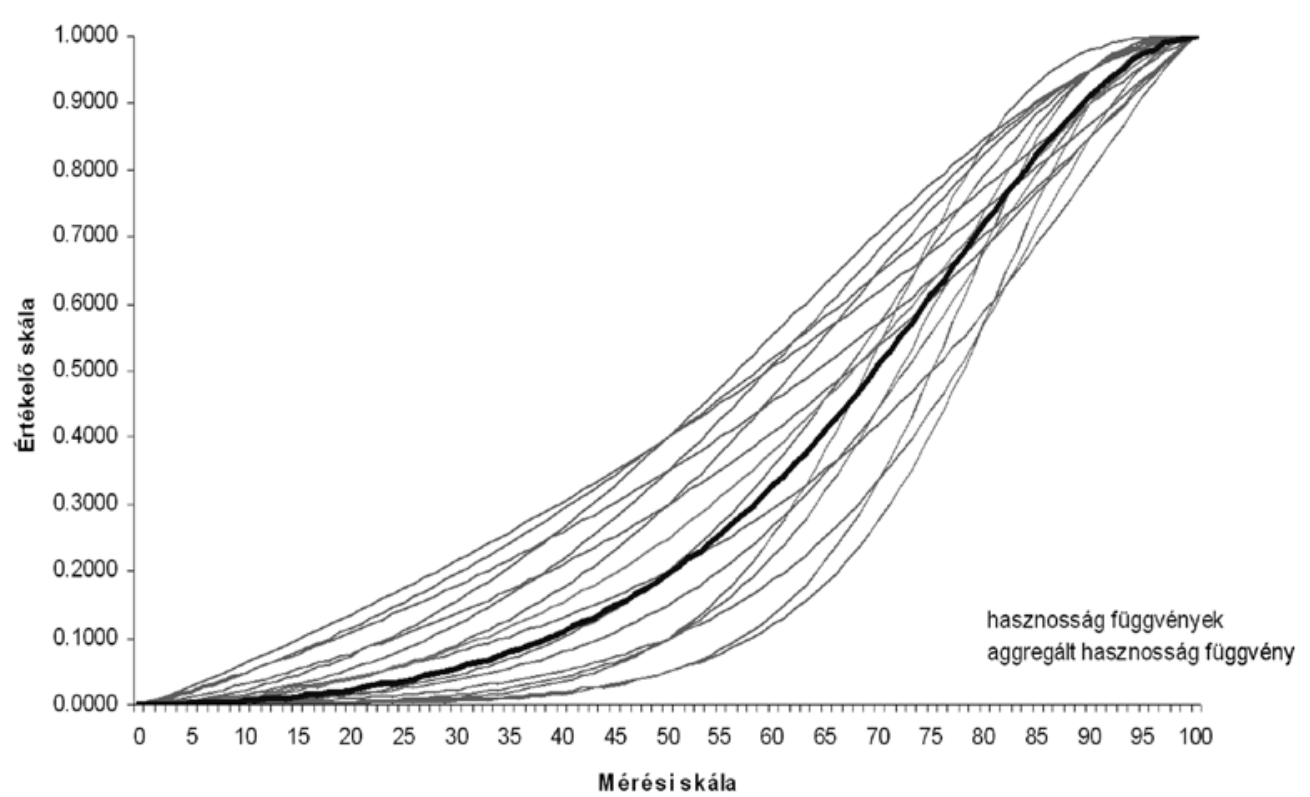

4. ábra

Az ÉVE-ÉHÉVP és ÉVE-LTVP eltérésekre a 6. táblázatban látható leíró statisztikai eredmények, valamint a különbségértékek 5. ábra szerinti box plot ábrázolása azt sugallják, hogy az ÉVE-ÉHÉVP különbség várható értéke közelebb van a nullához, mint az ÉVE-LTVP különbség várható értéke, illetve ÉVE-ÉHÉVP becsült szórása lényegesen kisebb, mint az ÉVE-LTVP különbségé.

Ez a gyakorlat szempontjából azt jelenti, hogy az általunk alkalmazott módszer (ÉVEÉHÉVP különbség) pon5. táblázat tosabb (mivel várható értéke közelebb van a nullához) és Az ÉVE-ÉHÉVP és ÉVE-LTVP eltérések

\begin{tabular}{|c|c|c|}
\hline Vevő & ÉVE-ÉHÉVP & ÉVE-LTVP \\
\hline $\mathbf{1}$ & $-0,0347$ & $-0,2888$ \\
\hline $\mathbf{2}$ & 0,0164 & $-0,1074$ \\
\hline $\mathbf{3}$ & 0,0014 & 0,0510 \\
\hline $\mathbf{4}$ & 0,0141 & $-0,0937$ \\
\hline $\mathbf{5}$ & 0,0115 & $-0,0127$ \\
\hline $\mathbf{6}$ & 0,0555 & 0,0722 \\
\hline $\mathbf{7}$ & 0,0252 & $-0,2016$ \\
\hline $\mathbf{8}$ & 0,0291 & $-0,1660$ \\
\hline $\mathbf{9}$ & $-0,0121$ & 0,0394 \\
\hline $\mathbf{1 0}$ & $-0,0195$ & $-0,0300$ \\
\hline $\mathbf{1 1}$ & 0,0087 & $-0,0355$ \\
\hline $\mathbf{1 2}$ & $-0,0103$ & $-0,0960$ \\
\hline $\mathbf{1 3}$ & $-0,0074$ & 0,0410 \\
\hline $\mathbf{1 4}$ & $-0,0096$ & $-0,0905$ \\
\hline $\mathbf{1 5}$ & 0,0050 & $-0,0310$ \\
\hline $\mathbf{1 6}$ & 0,0177 & 0,0600 \\
\hline $\mathbf{1 7}$ & $-0,0046$ & $-0,0585$ \\
\hline $\mathbf{1 8}$ & 0,0297 & 0,0835 \\
\hline $\mathbf{1 9}$ & 0,0613 & $-0,0521$ \\
\hline $\mathbf{2 0}$ & $-0,0663$ & $-0,1560$ \\
\hline $\mathbf{2 1}$ & $-0,0099$ & 0,0399 \\
\hline $\mathbf{2 2}$ & $-0,0393$ & $-0,4017$ \\
\hline $\mathbf{2 3}$ & $-0,0122$ & $-0,0260$ \\
\hline & & \\
\hline
\end{tabular}

\section{Leíró statisztika az ÉVE-ÉHÉVP} és ÉVE-LTVP eltérésekre

6. táblázat

\begin{tabular}{|c|c|c|c|c|}
\hline Változó & Átlag & Szórás & Medián & Terjedelem \\
\hline ÉVE-ÉHÉVP & 0,00216 & 0,02885 & 0,00143 & 0,12756 \\
\hline ÉVE-LTVP & $-0,06350$ & 0,11980 & $-0,03550$ & 0,48520 \\
\hline
\end{tabular}

\section{Az ÉVE-ÉHÉVP és ÉVE-LTVP eltérések box-plot ábrázolása}

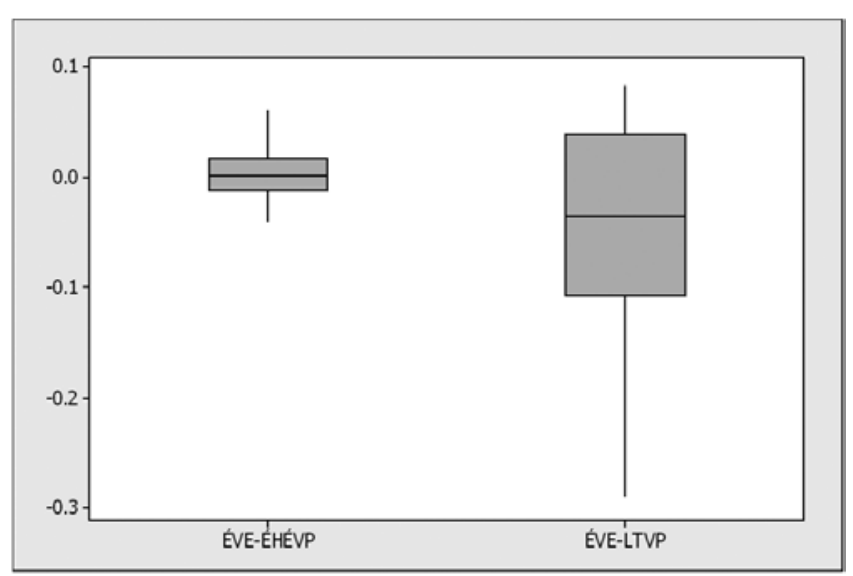


A végrehajtott AndersonDarling normalitásvizsgálatok alapján mind az ÉVE-ÉHÉVP, mind az ÉVE-LTVP eltérés esetén 0,05-ös szignifikanciaszinten elfogadható az a nullhipotézis, hogy a különbség normális eloszlást követ. A 6. és a 7. ábrák a normalitáspróbák eredményeit és az eltérésértékek Gauss-papíron történô ábrázolását mutatják. A normalitáspróba p-értéke az ÉVE-ÉHÉVP változó esetén magasabb $(0,565)$, mint az ÉVE-LTVP különbséghez tartozó p-érték $(0,077)$, ami azt jelenti, hogy ÉVE-ÉHÉVP eloszlása jobban illeszkedik egy normális eloszláshoz, mint az ÉVE-LTVP eloszlása. A gyakorlatban ez azt jelenti, hogy a módszerünk kevésbé torzít, ahhoz képest, mintha a mért értékeket egyszerú lineáris transzformációval értékelnénk.

\section{Normalitáspróba az ÉVE-ÉHÉVP különbségre}

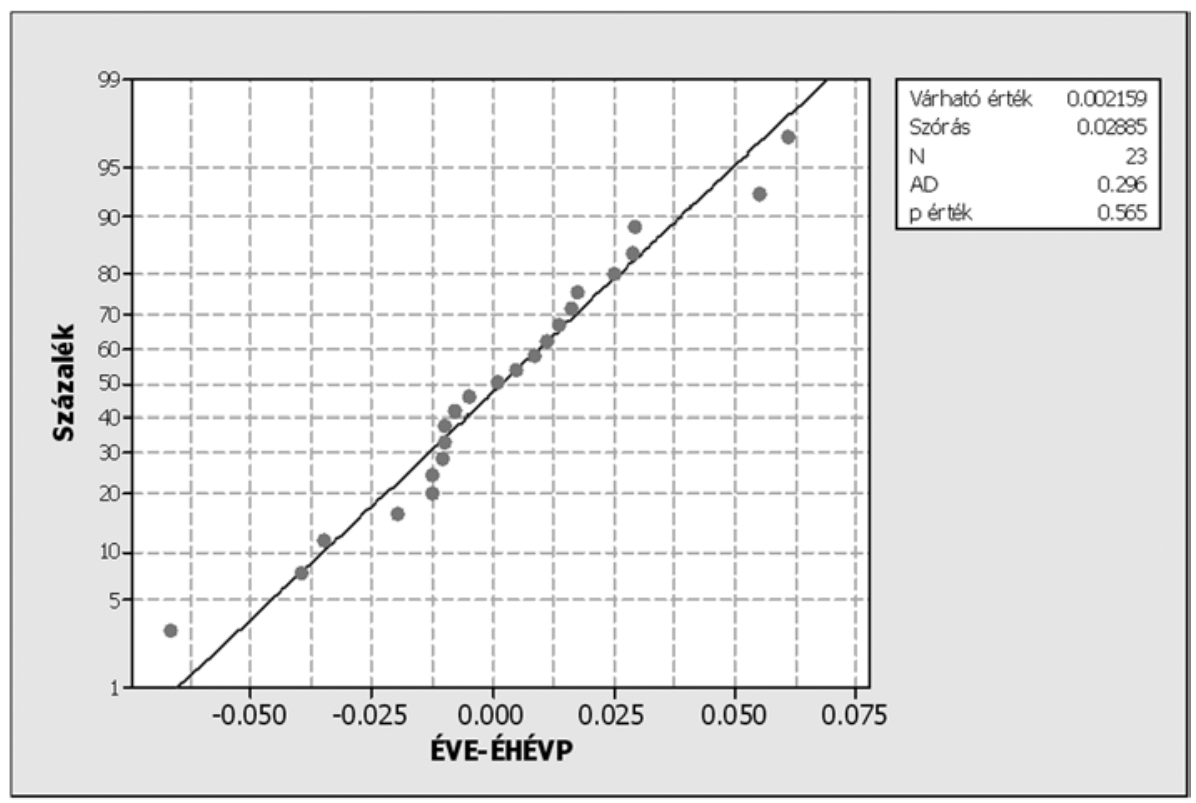

Normalitáspróba az ÉVE-LTVP különbségre

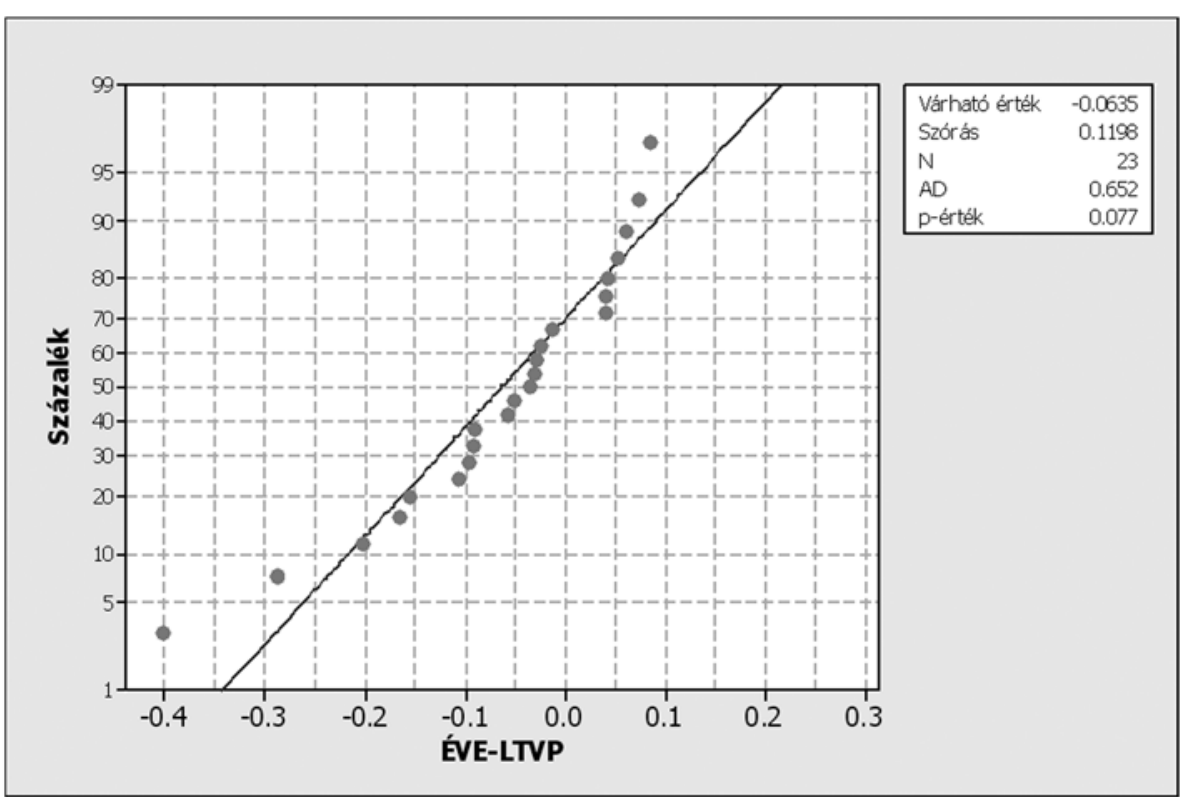

vizsgálat csak 0,077-es p-értéket eredményezett $(0,05$ ös szignifikanciaszint mellett), ezért azt a nullhipotézist, 6. ábra hogy a két különbség szórásának különbsége zérus, mind az F-próba, mind pedig a Levene-féle próba segítségével teszteltük 0,05 -ös szignifikanciaszinten. Az F-próba 0 -ás p-értéke és a Levene-féle próba 0,001-es p-értéke alapján elvetettük az ÉVE-ÉHÉVP és az ÉVE-LTVP különbségek szórásának egyenlőségére vonatkozó nullhipotézist és megállapítottuk, hogy a két szórás között szignifikáns különbség van. A 8. ábra a két szórásértékre vonatkozó 95\%-os megbízhatósági szintú konfidencia-intervallumokat, valamint az adatok box-plot ábrázolását mutatja. Ebból jól látszik, hogy az ÉVE-LTVP szórása jóval nagyobb, mint az ÉVE-ÉHÉVP szórása, tehát módszerünk megbízhatóbb.

Azt a hipotézisünket, miszerint az ÉVE-ÉHÉVP szórása kisebb, mint az ÉVE-LTVP szórása, kétmintás F-próbával és Levene-féle próbával is ellenôriztük. Mivel mind az ÉVE-ÉHÉVP, mind ÉVE-LTVP normális eloszlásúnak tekinthetô, így elegendő lett volna az F-próbával történő vizsgálat. Ugyanakkor láttuk, hogy az ÉVE-LTVP különbségre végrehajtott normalitás-
Az ÉVE-ÉHÉVP és az ÉVE-LTVP különbségek várható értékeinek eltérését kétmintás t-próbával vizsgáltuk. Abból a nullhipotézisból indultunk ki, hogy a két változó várható értékeinek különbsége zérus. A nullhipotézist 0,05-ös szignifikanciaszint mellett teszteltük. A kétmintás t-próba 0,017-es p-értéket eredményezett, s ez alapján a nullhipotézisünket elvetettuik, 
illetve megállapítottuk, hogy a két különbség várható értéke között szignifikáns különbség van.

Az aggregált hasznosság (értékelô) függvény helyettesítési értéke az aggregált 83,66-os vevői pontszámnál 0,7507 , és az aggregált vevơi pontszám lineáris transzformáltja a 0-1 értékelô skálán 0,8366. Ha e két értéket összevetjük az észlelt vevői elégedettségek 0,76-os súlyozott átlagértékével, akkor elmondhatjuk, hogy a paraméter-súlyozású aggregált értékelési módszer jól modellezi a vevơk elégedettségükhöz kapcsolt észleléseit.

Az értékelő függvények alkalmazásával a vevői elégedettség értékelésekor a vevőnek a hagyományos pontozáson túl választ kell adnia a függvények kalibrálásához szükséges kérdésekre. A módszer alkalmazása többletfeladatot jelent a vállalat számára is. Ám az értékelő függvények alkalmazásának lényegét megértve, $\mathrm{s}$ azokat helyesen alkalmazva, a vevői elégedettség megbízhatóbb értékeléséhez jutunk.

\section{Összegzés}

Az intellektuális tốkét mint rendelkezésre álló erőforrást a vállalat szervezete szempontjából kell tekintenünk, azaz nem a mért nagyságok számítanak, hanem azok az érzékelt értékek, amelyeket a szervezet az egyes mért értékekhez társít.

Egy olyan megközelítést mutattunk be, amelynek alapgondolata a mutatószámrendszer-alapú méréssel együtt járó bizonytalanságok és torzító hatások elfoga-

Az ÉVE-ÉHÉVP és ÉVE-LTVP különbségek szórásainak összehasonlítása

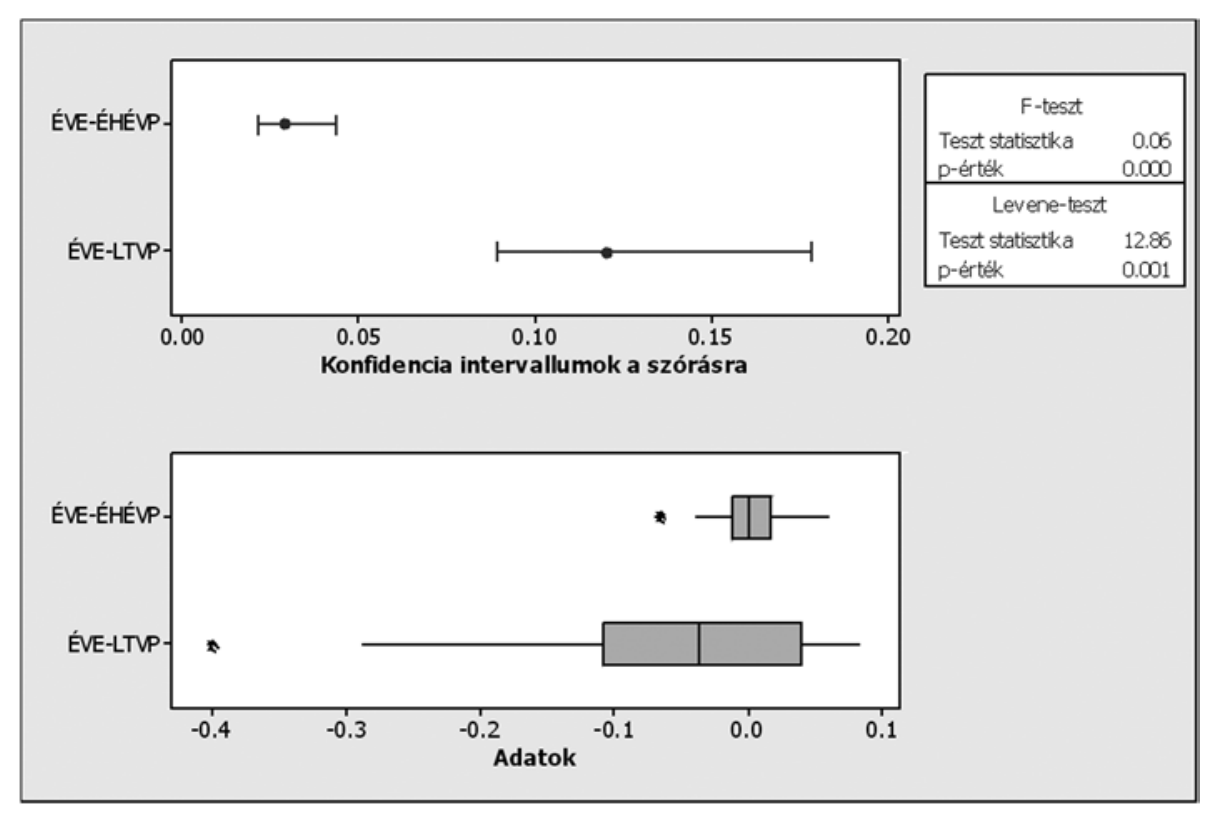
sére és aggregálására.

dása mellett a mérés és értékelés szétválasztása. A mérőrendszer által szolgáltatott mértékeket felülértékeljük a vállalat értékrendjét megtestesítő értékelő függvények segítségével. Az értékelő függvények paramétereivel a vállalat intellektuális tókeelemekre vonatkozó preferenciái jutnak kifejezésre, ezért az értékelés eredményeként az intellektuális tókeelemek vállalati értékének egy jobb közelítéséhez jutunk.

Kulcskérdés, hogy az intellektuális tóke a szervezet céljaihoz milyen mértékben tud hozzájárulni, azokat hogyan és milyen mértékben képes szolgálni. E hozzájárulási képesség mértékének megadása egyrészt az intellektuális tóke értékelését, másrészt pedig a szervezet szempontjából tekintett hasznosságának a meghatározását jelenti. Feltételezve, hogy az érvényes stratégiai célok teljesülését szolgáló intellektuális tốkeelemekkel kíván a szervezet foglalkozni, az elemekhez kapcsolódó kulcsfontosságú indikátorok megválasztásával, illetve az értékelő és aggregált értékelő függvények segítségével az intellektuális tốkeelem mérése és értékelése különválasztható, és a szervezeti célokhoz való hozzájárulása, hasznossága is értékelhetô. A strukturális és humán tốke kulcsfontosságú elemeit és a hozzájuk kapcsolódó mutatószámokat megválasztva a fentebb vázolt módszerek a vevői tókéhez hasonlóan alkalmazhatók a mérórendszer által mért értékek „felülértékelésére”, valamint a hasznosságok kifejezé-

Megközelítésünkkel hidat képezünk a pénzügyi és nem pénzügyi értékelési módszerek között, hiszen meg-

8. ábra adjuk annak a lehetôségét, hogy az intellektuális tốke egyes öszszetevôit pénzben mérjük, majd az értéket reprezentáló pénzérték hasznosságát kifejezzük.

További kutatási céljaink között szerepel a bemutatott módszerek más intellektuális tốkeelemek esetében való alkalmazásának vizsgálata, így pl. a munkatársi elégedettség, a technológiabevezetés, a toborzás és kiválasztás, valamint képzési programok értékelésénél. További kutatásokat igényel az, hogy az intellektuális tóke mérése és értékelése hogyan használható vállalati döntések bemeneteként, illetve hogy a vállalati célkitúzésekból hogyan lehet levezetni az elérésükhöz szükséges intellektuális tốkeelemek értékét. 


\section{Lábjegyzet}

A munka szakmai tartalma kapcsolódik a „Minôségorientált, öszszehangolt oktatási és K+F+I stratégia, valamint múködési modell kidolgozása a Múegyetemen" c. projekt szakmai célkitúzéseinek megvalósításához. A projekt megvalósítását az ÚMFTTÁMOP4.2.1/B-09/1/KMR-2010-0002 programja támogatja.

${ }^{1}$ Az ábrán szereplő rövidítések:

ROA: Return On Assets, VAIC: Value Added Intellectual Coefficient, EVA: Economic Value Added, CIV: Calculated Intangible Value, IAMV:Investor Assigned Market Value, FiMIAM: Financial Method of Intangible Asset Measurement, HRCA: Human Resource Costing and Accounting, AFTF:Accounting for the Future

${ }^{2}$ A 4. táblázat jelöléseinek magyarázata a következó:

- AP: aggregált pontszám, vagyis az egyes vevốk által adott pontszámok súlyozott átlaga

- VS: vevói súlyok, a vállalat által a vevốkhöz rendelt súlyszámok

- VEE: vevő érzékelt elégedettsége a $(0,1)$ skálán (a vevớk 3. kérdésre adott válaszai)

- ÉHÉVP: értékelő függvény helyettesítési értéke a vevő által adott pontszámnál, azaz az AP helyen (az egyes vevớk által adott pontszámokhoz az értékelő függvények által rendelt elégedettség a $(0,1)$ skálán)

- LTVP: lineárisan transzformált vevői pontszám, azaz a 0-100 mérési skáláról a 0-1 értékelési skálára lineárisan transzformált vevơi pontértékek.

\section{Felhasznált irodalom}

AREOPA (2005): Measuring the unmeasurable. (Forrás: www. areopa.com, 2008. május)

Andriessen, D. (2001): Weightless Wealth: Four modifications to standard IC theories. Journal of Intellectual Capital, 3. 204-214. o.

Andriessen, D. (2004): IC valuation and measurement. Journal of Intellectual Capital, 2. 230-242. o.

Andriessen, D. - Tissen, R. (2000): Weightless Wealth: Find Your Real Value in a Future of Intagible Assets, FT Prentice-Hall, London

Boda Gy. (2005): A tudástóke kialakulása és hatása a vállalati menedzsmentre. PhD-értekezés, Budapesti Múszaki és Gazdaságtudományi Egyetem, Gazdálkodás- és Szervezéstudományi Doktori Iskola

Boda Gy. (2008): A tudástôke mérési módszerei és használhatóságuk. CEO magazin, 3. melléklet

Bontis, N. (2001): Assessing knowledge assets: review of the models used to measure intellectual capital. International Journal of Management Reviews, 1. 41-60. o.

Burdick, R.K. - Borror, C.M. -Montgomery, D.C. (2005): Design and Analysis of Gauge R\&R Studies. SIAM, Philadelphia

Chen, J. - Cheng, S.J. - Hwang, Y. (2005): An empirical investigation of the relationship between intellectual capital and firms' market value and financial performance. Journal of Intellectual Capital, 2. 159176. $\mathrm{o}$.
DATI (Danish Agency for Trade and Industry) (1998): Intellectual Capital Accounts: New Tool for Companies. DTI Council, Copenhagen

DATI (1999): Developing Intellectual Capital Accounts: Experiences From 19 Companies. Ministry of Business and Industry, Copenhagen

Dombi, J. (1990): Membership function as an evaluation. Fuzzy Sets and Systems, 1. 1-21. o.

Edvinsson, L. - Kivikas, M. (2007): Intellectual capital or Wissensbilanz process: some German experiences. Journal of Intellectual Capital, 3. 376-385. o.

Edvinsson, L. - Malone, M.S. (1997): Intellectual Capital: Realizing Your Company's True Value by Finding its Hidden Brainpower. HarperBusiness Press, New York, NY

Fisher, J.C. - P Ry, R.H. (1971): A Simple Substitution Model of Technological Change. Technological Forecasting \& Social Change, 3. 75-88. o.

Fornell, C. - Johnson, M.D. - Anderson, E.W. - Cha, J. Bryant, B.E. (1996) The American customer satisfaction index: nature, purpose and findings. Journal of Marketing, 4. 7-18. o.

Grigoroudis, E. - Siskos, Y. - Saurais, O. (2000): TELOS: A customer satisfaction evaluation software. Computers \& Operations Research 27. 799-817. o.

Guthrie, J. - Petty, R. - Ferrier, F. - Wells, R. (1999): There is no accounting for intellectual capital in Australia: review of annual reporting practices and the internal measurement of intangibles within Australian organizations. Paper presented at the OECD conference in Amsterdam, June 1999

Hauszmann J. (2006): Kockázat és megbízhatóság a menedzsmentben. PhD-értekezés, Budapesti Múszaki és Gazdálkodástudományi Egyetem, Gazdálkodás- és Szervezéstudományi Doktori Iskola

Hong-Yu, L. - Jian, L. - Yun-Xian, G. (2006): Design of customer satisfaction index system of EMS service. The Journal of China Universities of Posts and Telecommunications 1. 1-5. o.

Homburg, C. - Stock, R.M. (2004): The link between salespeople's job satisfaction and customer satisfaction in a business-to-business context: a dyadic analysis. Journal of the Academy of Marketing Science 2. 144-158. o.

Johanson, U. - Martensson, M. - Skoog, M. (2001): Measuring to understand intangible performance drivers. The European Accounting Review, 3. 407-437. o.

Johnsen, T. - Philips, W. - Caldwell, N. - Lewis, M. (2006): Centrality of customer and supplier interaction in innovation. Journal of Business Research 6. 671-678. o.

Johnson, M.D. - Fornell, C. (1991): A framework for comparing customer satisfaction across individuals and product categories. Journal of Economic Psychology, 2. 267-286. o.

Jónás T. (2010): Aggregált megbízhatósági és minőségi mutatók változásainak modellezése. Minôség és Megbízhatóság, 3. 140-150. o. 
Juhász P. (2004): Az üzleti és a könyv szerinti érték eltérésének magyarázata - Vállalatok mérlegen kívüli tételeinek értékelési problémái, Ph.D. értekezés, Budapesti Corvinus Egyetem, Gazdálkodástani Doktori Iskola

Kaplan, R.S. - Norton, D.P. (1996): The Balanced Scorecard - Translating Strategy into Action. Harvard Business School Press, Boston, MA

Kivikas, M. - Pfeifer, G. (2005): Wissensbilanzierung als Chance für den Standort Deutschland: ein Fallbeispiel, FinanzBetrieb, 12. 799-807. o.

KPMG (2000): Tudásmenedzsment Magyarországon - Felmérés 2000; http: //www.kpmg.hu / dbfetch / 52616 e646f6d4956113ea0a80d1decf61d3956f60c93eb84 / knowledge_management_survey_in_hungary_-_2000. pdf, 2007. október

KPMG-BME Akadémia - Pannon Egyetem (2006): Tudásmenedzsment Magyarországon 2005/2006. KBA Oktatási Kft., Budapest, http://www.doc.hu/tm/tmriport2005. pdf, 2008. január

Leliaert, P.J.C. - Candries, W. - Tilmans, R. (2003): Identifying and managing IC: a new classification. Journal of Intellectual Capital 2. 202-214. o.

Lovdal, H. - Roberts, H. (1999): Norway: competence capital, paperpresented at the International Symposium Measuring and Reporting Intellectual Capital: Experiences, Issues and Prospects. Amsterdam, June, http://www.oecd.org/ dataoecd/16/22/1947894.pdf, January 2008

Modis, T. (1992): Predictions: Society's Telltale Signature Reveals the Past and Forecasts the Future. Simon \& Schuster, New York

Rogelberg, S.G. - Barnes-Farrell, J.L. - Creamer, V. (1999): Customer service behavior: the interaction of service predisposition and job characteristics. Journal of Business and Psychology, 3. 421-435. o.
Roos, G. - Roos, J. (1997): Measuring your company's intellectual performance. Long Range Planning, 3. 413426. o.

Roos, J. - Roos, G. - Dragonetti, N.C. - Edvinsson, L. (1997): Intellectual Capital: Navigating the New Business Landscape. Macmillan, London

Stewart, T.A. (1997): Intellectual Capital, The New Wealth of Organizations. Doubleday Publishing, New York

Sveiby, K.E. (2001-2005): Methods for Measuring Intangible Assets. http://www.sveiby.com/Portals/0/articles/ IntangibleMethods.htm, 2008 január

Sveiby, K.E. (1997): The New Organizational Wealth. Berrett-Koehler Publishers, San Francisco

Tóth Zs. E. (2008): Az intellektuális tốke mérési lehetőségeinek vizsgálata önértékelési modellek alapján. PhDértekezés, Budapesti Múszaki és Gazdaságtudományi Egyetem, Gazdálkodás- és Szervezéstudományi Doktori Iskola

Verhulst, P.F. (1845): Recherches mathématiques sur la loi d'accroissement de la population. Nouveaux Mémoirs de l'Académie Royale des Sciences et des Belles-Lettres de Bruxelles. 1-42. o.

Waterhouse, J. - Svendsen, A. (1998): Strategic Performance Monitoring and Management. CICA, Toronto

Zadeh, L.A. (1999): From computing with numbers to computing with words - From manipulation of measurements to manipulation of perceptions. IEEE Transactions on Circuits and Systems - I: Fundamental Theory and Applications, 1. 105-119. o.

Cikk beérkezett: 2010 . 5. hó

Lektori vélemény alapján véglegesítve: 2010. 9. hó 